\title{
MEDIASI SEBAGAI UPAYA PENYELESAIAN MASALAH ANTARA PT. ANEKA SUMBERBUMI JAYA DENGAN WARGA DESA BUMISARI KECAMATAN NATAR LAMPUNG SELATAN
}

\author{
MEDIATION AS PROBLEM SOLVING EFFORTS BETWEEN \\ PT. ANEKA SUMBERBUMI JAYA WITH RESIDENTS OF THE VILLAGE \\ BUMISARI DISTRICT OF NATAR OF SOUTH LAMPUNG
}

\author{
Aprilia Rahmawati, Muher Sukmayanto*, Helvi Yanfika \\ Jurusan Magister Penyuluhan dan Komunikasi Pertanian, Fakultas Pertanian, Universitas Lampung, \\ J1. Prof. Dr. Soemantri Brodjonegoro No.1 Bandar Lampung 35145, Telp. 082178127495 \\ *Email: muhersukmayanto7@gmail.com \\ (Diterima 25-02-2019; Disetujui 16-07-2019)
}

\begin{abstract}
ABSTRAK
Penelitian ini menganalisis: (1) pelaksanaan mediasi sebagai metode penyelesaian masalah yang terjadi antara PT Aneka Sumberbumi Jaya dengan Warga Desa Bumisari Kecamatan Natar Lampung Selatan, dan (2) hambatan dalam pelaksanaan mediasi sebagai metode penyelesaian masalah yang terjadi antara PT Aneka Sumberbumi Jaya dengan Warga Desa Bumisari Kecamatan Natar Lampung Selatan. Penelitian ini dilakukan di Desa Bumisari Kecamatan Natar Lampung Selatan. Pemilihan lokasi penelitian dilakukan secara sengaja (purposive). Informan penelitian ini terdiri atas kepala tambang yang merupakan perwakilan dari perusahaan, perwakilan warga Desa Bumisari, kepala desa serta perwakilan dari Polsek Natar sebagai mediator. Metode yang digunakan dalam penelitian ini adalah metode deskriptif dengan data yang digunakan adalah data primer dan data sekunder. Hasil penelitian menunjukkan bahwa: (1) Proses mediasi yang dilakukan oleh PT Aneka Sumberbumi Jaya dan warga Desa Bumisari berlangsung dengan baik yang dilakukan dengan 6 tahapan, yaitu penyampaian kehendak pihak yang bersengketa, deskripsi situasi dan identifikasi perkara, pemetaan masalah, menghasilkan alternatif-alternatif penyelesaian sengketa, evaluasi dan pemilihan alternatif dan merumuskan kesepakatan, dan (2) Hambatan dalam pelaksanaan mediasi antara PT Aneka Sumberbumi Jaya dengan warga Desa Bumisari yaitu kurangnya kesadaran dari pihak perusahaan dalam melaksanakan hak dan kewajiban yang harus dilaksanakan kepada masyarakat. Hambatan lain yaitu sikap egois dari masing-masing pihak yang bersengketa yang menyebabkan penyelesaian masalah berlangsung secara kaku dan berbelit-belit sehingga memakan waktu yang cukup panjang.
\end{abstract}

Kata kunci: Konflik, Masyarakat, Mediasi, Perusahaan

\begin{abstract}
This study analyzes: (1) the implementation of mediation as a method of resolving problems that occur between PT Aneka Sumberbumi Jaya and Residents of Bumisari Village, Natar Subdistrict, South Lampung (2) obstacles in conducting mediation as a method of resolving problems that occur between PT Aneka Sumberbumi Jaya and Bumisari Village Residents Natar District, South Lampung. This research was conducted in Bumisari Village, Natar District, South Lampung. The selection of research locations was done purposively. The informants from this study consisted of the Head of the mine who was a representative of the company, representatives of the residents of Bumisari Village, the village head and representatives of the Natar Police Sector as a mediator. The method used in this research is descriptive method with the data used are primary data and secondary data. The results showed that: (1) The mediation process carried out by PT Aneka Sumberbumi Jaya and Bumisari villagers proceeded well with 6 stages, namely the delivery of the wishes of the disputing parties, description of the situation and case identification, problem mapping, resulting settlement alternatives disputes, alternative evaluations and elections and formulating agreements (2) Obstacles in the mediation between PT Aneka Sumberbumi Jaya and Bumisari
\end{abstract}




\section{MEDIASI SEBAGAI UPAYA PENYELESAIAN MASALAH ANTARA PT. ANEKA SUMBERBUMI JAYA DENGAN WARGA DESA BUMISARI KECAMATAN NATAR LAMPUNG SELATAN \\ Aprilia Rahmawati, Muher Sukmayanto, Helvi Yanfika}

Village residents are the lack of awareness of the company in carrying out the rights and obligations that must be carried out to the community. Another obstacle is the selfish attitude of each party in dispute that causes problem solving to take place in a rigid and convoluted manner that takes a long time.

Keywords: Company, Conflict, Mediation, Society

\section{PENDAHULUAN}

Dalam kehidupan sehari-hari dan dalam kehidupan bisnis, sengketa atau konflik seringkali terjadi di tengah masyarakat. Konflik merupakan suatu bentuk perbedaan atau pertentangan ide, pendapat, paham atau kepentingan di antara dua pihak atau lebih (Muspawi, 2014). Konflik merupakan bagian dari kehidupan manusia yang manusia memiliki perasaan, pendirian maupun latar belakang kebudayaan yang berbeda. Timbulnya konflik ini merupakan suatu pertanda akan adanya krisis dalam hubungan manusia. Konflik bukan sesuatu yang harus dihindari oleh masyarakat tetapi harus diatasi atau diselesaikan bahkan apabila memungkinkan konflik yang diatasi dapat melahirkan suatu kerjasama di dalam kehidupan bermasyarakat. Konflik sendiri dapat diselesaikan baik secara litigasi maupun non litigasi.

Penyelesaian konflik melalui metode litigasi yaitu suatu upaya penyelesaian masalah atau konflik dengan bantuan hukum negara yang berlaku. Sementara metode non litigasi merupakan penyelesaian masalah di luar jalur hukum. Salah satu upaya penyelesaian konflik atau permasalahan yang ada di masyarakat dengan metode non litigasi yaitu dengan mediasi. Mediasi merupakan suatu upaya penyelesaian masalah atau konflik yang dilakukan oleh para pihak yang bermasalah dengan bantuan perantara yang tidak memiliki kewenangan memutus. Ada banyak keuntungan dari mekanisme mediasi ini, antara lain penyelesaiannya yang bersifat informal dan diselesaikan sendiri oleh para pihak, sehingga akan sesuai dengan kemauan para pihak yang memang paling mengetahui duduk masalahnya. Mediasi tidak membutuhkan waktu yang lama dalam penerapannya, sepanjang para pihak yang bermasalah memiliki iktikad baik. Melalui mediasi hubungan para pihak yang bersengketa tetap kooperatif dan terjalin dengan baik, karena kunci dari mediasi adalah berlangsungnya musyawarah dengan bantuan seorang mediator yang berfungsi sebagai penengah yang bersifat netral. Penyelesaian permasalahan yang terjadi antara pihak-pihak yang bersengketa 
diharapkan tidak hanya ada pihak yang menang dan kalah, tetapi dapat memenuhi keinginan dari kedua belah pihak tersebut dengan win-win solution.

Banyak permasalahan di dalam kehidupan bermasyarakat yang diselesaikan dengan mediasi, salah satunya yaitu permasalahan antara perusahaan dengan warga masyarakat yang bermukim di sekitar perusahaan. Aktivitas perusahaan yang berada di dekat pemukiman warga seringkali memicu terjadinya suatu konflik. Hal itu dapat terjadi apabila warga masyarakat merasakan suatu dampak negatif dari adanya kegiatan perusahaan tersebut. Salah satu konflik yang terjadi yaitu konflik antara PT Aneka Sumberbumi Jaya dengan warga Desa Bumisari Kecamatan Natar Lampung Selatan yang berada di sekitar perusahaan. PT Aneka Sumberbumi Jaya merupakan perusahaan yang bergerak pada kegiatan pertambangan. Aktivitas pengeboman tambang, penggunaan alat berat dan jam kerja selama 24 jam menimbulkan suatu protes dan pertentangan dari warga masyarakat yang bermukim di sekitar perusahaan. Pertentangan tersebut tentunya membutuhkan suatu solusi yang terbaik untuk perusahaan dan warga desa dalam waktu yang singkat tanpa melalui suatu proses pengadilan yang memakan waktu dan biaya yang relatif tinggi. Berdasarkan latar belakang tersebut maka dilakukan suatu penelitian yang bertujuan untuk mengetahui: (1) Proses mediasi penyelesaian masalah yang terjadi antara PT Aneka Sumberbumi Jaya dengan Warga Desa Bumisari Kecamatan Natar Lampung Selatan, dan (2) Hambatanhambatan yang terjadi dalam penyelesaian masalah yang terjadi antara PT Aneka Sumberbumi Jaya dengan Warga Desa Bumisari Kecamatan Natar Lampung Selatan.

\section{METODE PENELITIAN}

Penelitian dilakukan pada bulan November 2018 di Desa Bumisari Kecamatan Natar Lampung Selatan. Informan dari penelitian ini terdiri atas perwakilan dari perusahaan, warga desa Bumisari, kepala desa dan perwakilan Polsek Natar sebagai mediator. Metode yang dipergunakan dalam penelitian ini adalah metode deskriptif. Metode deskriptif adalah suatu metode yang berupaya memecahkan atau menjawab permasalahan yang dihadapi dalam situasi sekarang. Rianto (1996) menyatakan bahwa penelitian deskriptif adalah penelitian yang diarahkan untuk menjelaskan tentang gejala-gejala, faktafakta atau kejadian-kejadian secara 


\section{MEDIASI SEBAGAI UPAYA PENYELESAIAN MASALAH ANTARA PT. ANEKA SUMBERBUMI JAYA DENGAN WARGA DESA BUMISARI KECAMATAN NATAR LAMPUNG SELATAN \\ Aprilia Rahmawati, Muher Sukmayanto, Helvi Yanfika}

sistematis, akurat mengenai sifat-sifat populasi atau daerah tertentu.

Data yang digunakan dalam penelitian ini adalah data primer dan data sekunder. Data primer diperoleh langsung dari responden yaitu petani dan penyuluh melalui wawancara terstruktur dengan menggunakan kuesioner. Data primer meliputi semua data yang dikumpulkan melalui wawancara menggunakan kuesioner, wawancara mendalam (indepth interview), dan observasi. Data sekunder diperoleh dari studi kepustakaan, laporan, literatur, serta dari instansi yang berkaitan dengan penelitian yang dilakukan.

Dalam menganalisis data, penelitian ini menggunakan analisis data model interaktif Milles dan Huberman yaitu terdapat tiga proses yang berlangsung secara interaktif. Tiga proses tersebut yaitu pertama, reduksi data, yaitu proses memilih, memfokuskan, menyederhanakan, dan mengabstraksikan data dari berbagai sumber data misalnya dari catatan lapangan dokumen, arsip, dan sebagainya. Selanjutnya yaitu proses mempertegas, memperpendek, membuang yang tidak perlu, menentukan fokus, dan mengatur data sehingga kesimpulan bisa dibuat. Kedua, penyajian data, seperti merakit data dan menyajikan dengan baik supaya data menjadi lebih mudah untuk dipahami. Penyajian bisa berupa matrik, gambar, skema, jaringan kerja, tabel dan seterusnya. Ketiga yaitu menarik kesimpulan/verifikasi, proses penarikan kesimpulan awal belum masih kuat, terbuka dan skeptic. Kesimpulan akhir akan dilakukan setelah pengumpulan data berakhir (Sugiyono, 2010).

\section{HASIL DAN PEMBAHASAN}

Secara umum, hubungan antara perusahaan dan masyarakat sangat terkait dengan tiga hal besar, yaitu manajemen dampak, distribusi manfaat, serta perilaku perusahaan (Zandvliet dan Anderson, 2009; IFC, 2010). Tiga hal tersebut memiliki komponennya masing-masing. Manajemen dampak terdiri atas dampak langsung dan dampak tidak langsung. Distribusi manfaat terdiri atas peluang kerja, kesempatan usaha, dan projek komunitas. Perilaku perusahaan terkait dengan persepsi masyarakat yang ada di sekitar perusahaan.

Perusahaan harus mampu mengelola tiga aspek tersebut. Aspek yang pertama, yaitu manajemen dampak. Pada beberapa kasus ada perusahaan yang memiliki kinerja kurang baik dalam mengelola dampak dari aktivitas yang dilakukan, sehingga masyarakat marah. Pencemaran yang dibiarkan dan membuat masyarakat kehilangan daya dukung lingkungan sering kali membuat 
hubungan antara perusahaan dan masyarakat memburuk. Demikian juga, manajemen dampak sosial yang buruk misalnya dalam pembelian lahan yang juga seringkali menyebabkan terjadinya konflik antara perusahaan dengan masyarakat.

Aspek yang kedua, yaitu distribusi manfaat dari perusahaan. Hal penting yang harus diperhatikan adalah bagaimana keberadaan perusahaan tersebut dapat memberikan manfaat bagi masyarakat. Sudah menjadi hal yang mendasar bahwa perusahaan yang hadir di suatu wilayah tertentu harus memberikan manfaat utama bagi wilayah itu. Hal tersebut karena aktivitas yang dilakukan oleh perusahaan menimbulkan suatu dampak bagi masyarakat dan lingkungan. Sehingga perlu diseimbangkan dengan manfaat dari perusahaan tersebut bagi masyarakat dan lingkungan. Perusahaan harus dapat memilah mana saja jenis-jenis peluang kerja, kesempatan usaha, dan projek yang bisa ditujukan untuk masyarakat setempat. Adanya perusahaan diharapkan mampu membantu membangun masyarakat yang ada di wilayah tersebut yang dilakukan sesuai dengan kapasitas, aset, dan kebutuhan masyarakat itu.

Aspek yang ketiga, yaitu perilaku perusahaan. Perilaku perusahaan terkait bagaimana perusahaan menjalankan interaksi dengan masyarakat. Sikap perwakilan perusahaan dalam berhadapan dengan masyarakat menjadi aspek penting dalam penilaian masyarakat. Masyarakat menganggap bahwa perusahaan dan seluruh bagian dari perusahaan merupakan pendatang. Perilaku mereka menjadi suatu persepsi masyarakat yang sangat terkait dengan kepantasan sikap bagi seorang pendatang di wilayah tertentu. Perusahaan harus mengetahui bagaimana ekspektasi masyarakat terhadap perilaku perusahaan, sehingga perusahaan dapat menunjukkan hal-hal yang baik terkait hubungan dengan masyarakat.

Konflik yang terjadi antara perusahaan dan masyarakat tidak hanya berdampak negatif pada iklim investasi saja, namun juga akan memberikan pengaruh terhadap stabilitas sosial, politik dan keamanan di sebuah wilayah. Di dalam sebuah konflik, tidak akan ada pihak yang diuntungkan, semua pihak yang terlibat di dalam konflik tersebut sama-sama dirugikan. Kerugian tersebut akan dialami baik oleh perusahaan, masyarakat maupun pemerintah. Kelancaran operasional perusahaan akan terganggu, para karyawan tidak akan tenang dalam bekerja, dan citra perusahaan menjadi tidak baik. 


\section{MEDIASI SEBAGAI UPAYA PENYELESAIAN MASALAH ANTARA PT. ANEKA SUMBERBUMI JAYA DENGAN WARGA DESA BUMISARI KECAMATAN NATAR LAMPUNG SELATAN \\ Aprilia Rahmawati, Muher Sukmayanto, Helvi Yanfika}

\section{Penyebab Konflik antara Perusahaan dan Masyarakat}

Selama ini aktivitas di sektor perkebunan, pertambangan dan kehutanan menjadi tiga sektor usaha yang paling rawan terjadi konflik dengan masyarakat. Konflik dengan masyarakat sekitar sangat mungkin terjadi, karena tiga sektor usaha ini berkaitan langsung dengan penguasaan lahan yang cukup luas dan dampak perubahan lingkungan yang cukup besar dari kegiatan usaha yang dilakukan oleh perusahaan.

Selain masalah tersebut, masalah lain yang menjadi salah satu faktor utama penyebab konflik biasanya karena adanya suatu ketidakpuasan masyarakat terhadap kontribusi dan perhatian yang diberikan perusahaan kepada masyarakat setempat. Perusahaan dianggap hanya berorientasi untuk mencari keuntungan semata. Aktivitas perusahaan dianggap hanya mengeruk dan mengeksploitasi sumber daya alam yang ada di daerah tersebut, tanpa memperhatikan nasib masyarakat lokal yang tinggal disekitar perusahaan.

Konflik yang terjadi antara PT Aneka Sumberbumi Jaya dengan masyarakat di Desa Bumi Asri Kecamatan Natar Lampung Selatan juga diakibatkan adanya masalah tersebut. PT Aneka Sumberbumi Jaya merupakan suatu perusahaan yang bergerak di bidang pertambangan. Usaha yang dilakukan adalah pertambangan batu kapur dan produksi calcium carbonate yang digunakan untuk pertanian, perkebunan, industri, tambak dan bidang kegiatan lain. Pada pelaksanaan usahanya PT Aneka Sumberbumi Jaya terbagi atas dua site, yaitu tambang dan pabrik. Aktivitas tambang PT Aneka Sumberbumi Jaya dijalankan untuk menghasilkan bahan baku berupa batu kapur yang selanjutnya dikirim ke pabrik untuk dilakukan pengolahan. Aktivitas pertambangan ini yang memicu adanya konflik antara perusahaan dan masyarakat.

Masyarakat merasa dirugikan dengan aktivitas pertambangan yang dilakukan oleh PT Aneka Sumberbumi Jaya. Kerugian pertama yang dirasakan masyarakat yaitu aktivitas pengeboman batu yang dilakukan oleh perusahaan berdampak pada polusi udara di sekitar tambang. Debu dan pecahan batu akibat pengeboman yang dilakukan menyebar hingga sampai ke pemukiman warga. Hal tersebut tentunya sangat mengganggu masyarakat dalam beraktivitas di sekitar lingkungan. Kerugian yang kedua yaitu kerusakan jalan yang diakibatkan banyaknya mobil truk bermuatan besar yang hilir mudik mengangkut batu kapur baik dikirim untuk pabrik maupun yang dikirim untuk ke konsumen. Kerusakan 
jalan tersebut sangat mengganggu akses transportasi masyarakat, terlebih lagi ketika memasuki musim hujan. Jalanan menjadi becek, licin dan berlumpur sehingga sulit untuk dilewati. Masalah lain yang merugikan masyarakat yaitu kurangnya penyerapan tenaga kerja dari lingkungan sekitar. Banyak tenaga kerja yang diambil perusahaan berasal dari luar wilayah Bumisari. Hal tersebut tentunya menyebabkan masyarakat merasa iri karena kegiatan dilakukan di wilayah mereka, tetapi hanya $20 \%$ tenaga kerja yang berasal dari desa Bumisari. Masalah yang terakhir yaitu ada beberapa titik bekas aktivitas tambang yang ditinggalkan begitu saja. Bekas aktivitas tambang tersebut membentuk suatu lubang besar yang dikhawatirkan dapat membahayakan masyarakat. Lubang besar tersebut ketika hujan terisi penuh dengan air dan membentuk kolam yang luas dan dalam. Kolam tersebut sering digunakan sebagai tempat bermain bagi anak-anak yang apabila tidak berhati-hati dapat menyebabkan kecelakaan.

Protes masyarakat terhadap kerugian tersebut awalnya dilaksanakan secara bertahap. Pada tahap pertama, masyarakat diwakili oleh pemuka setempat mengajukan protes atau komplain kepada perusahaan. Komplain tersebut diterima oleh perusahaan dengan pemberian klarifikasi atas permasalahan tersebut. Namun setelah beberapa lama masyarakat merasa tidak ada respon berupa tindakan nyata dari perusahaan. Selanjutnya beberapa kali masyarakat mengajukan komplain kembali yang masih ditanggapi dingin oleh perusahaan hingga kesabaran masyarakat habis dan puncaknya masyarakat melaksanakan demonstrasi dan upaya penutupan tambang sementara.

\section{Proses Mediasi antara Perusahaan dan Masyarakat}

Proses mediasi dilaksanakan di PT Aneka Sumberbumi Jaya dengan menghadirkan perwakilan dari pihak perusahaan, perwakilan dari masyarakat kepala desa dan perwakilan dari Polsek Natar. Kepala desa dan perwakilan dari Polsek Natar bertindak sebagai mediator. Mediator bertugas menjembatani pihak pihak bersengketa untuk bisa menyelesaikan kasus dengan prinsip mutual winning. Hal ini bertujuan agar semua pihak yang terlibat di dalam konflik tidak ada yang merasa kalah atau dikalahkan karena setiap sengketa pasti diawali dengan ketidaksengajaan bahwa apa yang dilakukan merugikan pihak lain.

Berbeda dengan mediasi di pengadilan yang diwajibkan oleh majelis hakim, mediasi ini dilaksanakan atas 
kehendak para pihak yang terlibat di dalam konflik. Setelah para pihak menemui jalan buntu dalam menyelesaikan sengketanya, pihak perusahaan dan masyarakat bersepakat untuk meminta bantuan penengah atau mediator yang berasal dari kepala desa dan perwakilan Polsek Natar. Adapun langkah-langkah penyelesaian sengketa dengan mediasi ini adalah sebagai berikut:

\section{Penyampaian kehendak pihak yang} bersengketa, penentuan jadwal dan tempat pertemuan mediasi

Sebelum pihak yang terlibat di dalam konflik melakukan upaya mediasi, mereka telah gagal melakukan suatu upaya negosiasi bersama, selanjutnya kedua belah pihak sepakat untuk meminta bantuan pihak ketiga dalam penyelesaian masalahnya. Pihak ketiga yang dipilih yaitu kepala desa Bumiasri dan perwakilan Polsek Natar.

\section{Deskripsi situasi dan identifikasi perkara}

Pada tahap ini mediator mempertemukan dan mendengarkan penjelasan dari perwakilan pihak perusahaan dan perwakilan dari masyarakat yang bersengketa. Berdasarkan penjelasan dari kedua belah pihak, mediator dapat menemukan pokok masalah yang sebenarnya terjadi dan yang akan menjadi fokus dalam proses mediasi.

\section{Pemetaan masalah \& membingkai ulang permasalahan}

Tahap selanjutnya, mediator sebagai penengah merumuskan kembali pokok permasalahan yang terjadi dan menyampaikan hasil rumusannya kepada para pihak untuk memperoleh tanggapan. Setelah rumusan masalah disetujui kedua belah pihak, proses dilanjutkan dengan membuat pemetaan masalah untuk mengetahui prioritas permasalahan.

4. Menghasilkan alternatif-alternatif penyelesaian sengketa

Pada tahapan ini mediator diharapkan mampu untuk menghasilkan atau merumuskan tuntutan-tuntutan dan alternatif penyelesaian terhadap permasalahan yang ada. Alternatif penyelesaian yang dipilih oleh mediator pada konflik ini yaitu adanya pemberitahuaan terlebih dahulu kepada masyarakat sebelum melaksanakan pemboman site tambang oleh perusahaan sehingga masyarakat dapat bersiap diri ketika akan melakukan aktivitas di luar rumah. Penyelesaian masalah yang kedua yaitu perbaikan jalan dilakukan oleh perusahaan dengan menimbun jalan yang rusak dengan batu yang berasal dari site dengan pengerjaannya dibantu oleh 
warga masyarakat sekitar. Solusi masalah selanjutnya yaitu penambahan jumlah tenaga kerja dari masyarakat sekitar yang dilakukan bertahap karena perusahaan sedang dalam proses pengembangan sehingga belum membutuhkan banyak tenaga kerja. Penyelesaian masalah terakhir yaitu dengan menimbun lubang bekas aktivitas pertambangan dari pasir yang ada di tambang. Proses penimbunan ini nantinya dilakukan dengan alat berat dan dengan bantuan warga masyarakat sekitar secara gotong royong. Untuk penyelesaian pihak perusahaan mediator mengharapkan kegiatan pertambangan dapat berjalan kembali dengan aman sehingga pihak perusahaan juga tidak dirugikan.

\section{Evaluasi \& Pemilihan Alternatif- alternatif}

Tuntutan para pihak dan alternatif penyelesaian sengketa yang telah dibuat kemudian disusun menjadi serangkaian daftar alternatif. Daftar alternatif tersebut selanjutnya akan dianalisis oleh para pihak yang bersengketa. Para pihak diberi kesempatan untuk membahas dan mengkonsultasikan alternatif-alternatif tersebut kepada pihak lain lain, seperti notaris, pengacara ataupun berkonsultasi kepada mediator.

\section{Merumuskan kesepakatan}

Pada tahap terakhir ini, para pihak melakukan negosiasi final, yaitu klarifikasi ketegasan para pihak mengenai alternatif-alternatif bagi penyelesaian sengketa yang terjadi diantara mereka. Tercapainya kesepakatan final antara para pihak yang bersengketa, merupakan putusan untuk menyelesaikan dan mengakhiri sengketa. Dalam merumuskan Kesepakatan Perdamaian, mediator wajib memastikan kesepakatan tersebut tidak memuat ketentuan yang: a) bertentangan dengan hukum, ketertiban umum, dan/atau kesusilaan; b) merugikan pihak ketiga; atau c) tidak dapat dilaksanakan (Widihastuti, 2017).

Adapun kesepakatan yang dicapai antara kedua belah pihak yaitu perusahaan dapat beroperasi kembali seperti semula dan perusahaan harus melaksanakan alternatif penyelesaian masalah yang sudah disepakati sebelumnya yaitu memberikan pengumuman terlebih dahulu kepada masyarakat sekitar terkait aktivitas pengeboman yang akan dilakukan minimal tiga hari sebelum pelaksanaan. Selanjutnya perusahaan membantu upaya perbaikan jalan dengan mengirimkan sejumlah 


\section{MEDIASI SEBAGAI UPAYA PENYELESAIAN MASALAH ANTARA PT. ANEKA SUMBERBUMI JAYA DENGAN WARGA DESA BUMISARI KECAMATAN NATAR LAMPUNG SELATAN \\ Aprilia Rahmawati, Muher Sukmayanto, Helvi Yanfika}

material batu yang berasal dari site kemudian masyarakat membantu dalam proses perbaikannya. Masalah penyerapan tenaga kerja akan diselesaikan perusahaan dalam jangka waktu maksimal 3 bulan ke depan. Kondisi saat ini perusahaan sedang tahap ekspansi dan pembangunan mesin baru yang belum selesai di produksi sehingga belum membutuhkan tenaga kerja. Setelah pembangunan selesai perusahaan berjanji untuk menambah tenaga kerja dari lingkungan sekitar. Penutupan lubang bekas aktivitas tambang juga akan dilakukan oleh perusahaan dengan bantuan dari masyarakat sekitar.

\section{Hambatan dalam Pelaksanaan Proses Mediasi}

Pelaksanaan mediasi telah berhasil dilakukan dengan baik oleh kedua belah pihak. Meskipun demikian terdapat hal yang menghambat proses pengambilan keputusan atas konflik yang terjadi. Hal tersebut antara lain kurangnya kesadaran dari pihak perusahaan terhadap hak dan kewajiban yang harus dipenuhi kepada masyarakat sehingga memicu konflik terjadi. Perusahaan seperti mengulur waktu dan tidak memberikan respon atas komplain atau protes yang disampaikan oleh masyarakat. Hambatan lain yang dihadapi dalam proses penyelesaian konflik ini yaitu adanya sikap egois dari masing-masing pihak dalam mempertahankan kepentingan masing-masing. Adanya sikap egois ini berdampak pada proses pemecahan masalah yang berlangsung secara kaku dan berbelit-belit sehingga memakan waktu yang cukup panjang.

Peran mediator sangat penting untuk mengatasi hambatan tersebut, upaya yang dilakukan mediator antara lain dengan memberikan kesadaran baik dari pihak perusahaan maupun masyarakat mengenai hak dan kewajiban mereka masingmasing. Hal ini bertujuan agar dari pihak perusahaan maupun masyarakat samasama menyadari bahwa keberadaan keduanya merupakan hubungan yang saling membutuhkan satu sama lain. Perusahaan membutuhkan suatu iklim kerja yang kondusif untuk produktivitas usahanya, sementara masyarakat membutuhkan perusahaan untuk pembangunan warga masyarakat.

\section{KESIMPULAN}

1. Proses mediasi yang dilakukan oleh PT Aneka Sumberbumi Jaya dan warga Desa Bumisari berlangsung dengan baik yang dilakukan dengan 6 tahapan yaitu penyampaian kehendak pihak yang bersengketa, deskripsi situasi dan 
identifikasi perkara, pemetaan masalah, menghasilkan alternatifalternatif penyelesaian sengketa, evaluasi dan pemilihan alternatif dan merumuskan kesepakatan.

2. Hambatan dalam pelaksanaan mediasi antara PT Aneka Sumberbumi Jaya dengan warga Desa Bumisari yaitu kurangnya kesadaran dari pihak perusahaan dalam melaksanakan hak dan kewajiban yang harus dilaksanakan kepada masyarakat.

Hambatan lain yaitu sikap egois dari masing-masing pihak yang bersengketa yang menyebabkan penyelesaian masalah berlangsung secara kaku dan berbelit-belit sehingga memakan waktu yang cukup panjang.

\section{DAFTAR PUSTAKA}

Muspawi, Muhammad. 2014. Manajemen Konflik (Upaya Penyelesaian Konflik Dalam Organisasi). Jurnal Humaniora. Vol 16 (2): 41-46.

Mardhiah, Ainal. 2011.Penyelesaian Sengketa Melalui Mediasi Berdasarkan Perma No. 1 Tahun 2008. Jurnal Ilmu Hukum. Vol 53 (13) : 153-169

Sugiantari A, Solechan, Suhartoyo. 2016. Penyelesaian Perselisihan Hubungan Industrial melalui Mediasi di Dinas Tenaga Kerja dan Transmigrasi Kota Semarang. Dipenogoro Law Review. Vol 5 (2) : 1-10.

Widihastuti S, Hartini S, Kusdarini E. 2017. Mediasi Dalam Penyelesaian Sengketa Kesehatan di Jogja Mediation Center. Jurnal Ilmu-Ilmu Sosial. Vol 14 (1) : 15-25.

Wirawan. 2010. Konflik dan Manajemen konflik: Teori Aplikasi, dan Penelitian. Salemba Empat. Jakarta. 